\title{
STRATEGI PEMASARAN PRODUK SAYURAN DATARAN TINGGI DI WILAYAH KECAMATAN BATUR KABUPATEN BANJARNEGARA
}

\author{
Pujiharto \\ pharto@yahoo.co.id \\ Fakultas Pertanian Universitas Muhammadiyah Purwokerto \\ Sri Wahyuni \\ yuni_7067@yahoo.co.id \\ Fakultas Ekonomi dan Bisnis Universitas Muhammadiyah Purwokerto
}

\begin{abstract}
The purpose of this study was to: analyze vegetable marketing strategies carried out by highland vegetable farmers; and analyze what factors influence the marketing strategy implemented by highland vegetable farmers. This research includes descriptive-quantitative research. The research location was carried out purposively in the Batur Sub District of Banjarnegara District. Data retrieval is done through surveys, observations and interviews using questionnaires. The unit of analysis was the farmer who planted the main highland vegetable plants in the study area (potatoes, cabbage, carrots). Data analysis was carried out in a quantitative descriptive manner with a Likert scale on the data of mastering marketing strategies. The strategy undertaken by highland vegetable farmers in product marketing on price, product, distribution and promotion indicators is low.
\end{abstract}

Keywords: marketing strategies, highland vegetable products, Batur Subdistrict

\section{PENDAHULUAN}

Memasuki era globalisasi dan sejalan dengan pesatnya perkembangan ilmu pengetahuan dan teknologi, peranan informasi dalam pembangunan pertanian menjadi sangat penting. Informasi merupakan kunci bagi terciptanya pemahaman, terbukanya wawasan, membantu dalam pengambilan keputusan yang efektif dan efisien, sehingga pembangunan dapat berjalan dengan efektif dan efisien.

Pesatnya perkembangan teknologi komunikasi dan berhasilnya proses pembangunan berbagai prasarana fisik pertanian, seperti irigasi dan jaringan jalan, dan sarana telekomunikasi yang dapat menjangkau sebagian besar daerah-daerah pertanian telah mendorong terjadinya perubahan pola komunikasi para petani menjadi lebih terbuka. Mereka lebih mampu berkomunikasi dengan orang-orang diluar sistem sosialnya dan lebih mampu berkomunikasi secara non-personal melalui berbagai media masa dan media elektronik. Hal ini mengakibatkan mereka memiliki akses yang besar terhadap sumber-sumber informasi. Mereka dapat memanfaatkan sumber informasi tersebut dalam pengelolaan usahataninya dan bahkan dapat melakukan pengembangan usahataninya yang berorientasi pasar.

Pembangunan pertanian di Indonesia selama ini terjadi lebih mengutamakan untuk mengejar target produksi yang tinggi dengan mengabaikan faktor lainnya seperti pemasaran hasil, akibatnya salah satu 
subsistem dari sistem agribisnis yakni pemasaran hasil sangat jauh tertinggal/terhambat. Oleh sebab itu sekarang ini pemerintah melalui berbagai kebijakannya telah mencoba bagaimana supaya produk pertanian mampu bersaing baik dipasar lokal, nasional, maupun internasional. Dalam kenyataannya hingga saat ini sistem pemasaran hasil pertanian terasa masih kurang dipahami oleh petani, sehingga menempatkan petani pada posisi tawar menawar yang lemah. Salah satu faktor masalah yang menonjol adalah kurangnya pengetahuan petani dalam menerapkan startegi pemasaran hasil pertanian (Ameriana dan Soetiarso 1997).

Tantangan yang sering dihadapi petani dalam mengembangkan produk sayuran dataran tinggi, adalah relatif tingginya fluktuasi harga. Fluktuasi harga terjadi secara musiman, bulanan, mingguan, harian dan bahkan harga dapat berubah dua-tiga kali sehari. Fluktuasi harga yang terjadi dalam sehari biasanya terjadi pada komoditas sayuran yang cepat rusak, seperti kubis, tomat, bawang daun dan sawi. Terjadinya fluktuasi harga yang tinggi disebabkan

\section{METODE PENELITIAN}

\section{Metode Dasar}

Metode dasar yang digunakan dalam penelitian ini adalah metode deskriptif analisis, yaitu suatu metode penelitian yang memusatkan perhatian pada suatu permasalahan masa sekarang dengan jalan banyak faktor antara lain sifat musiman dari produk yang dihasilkan, sifat produk yang mudah rusak dan struktur pasar yang cenderung monopsonistik. Sifat produk yang mudah rusak ini membuat budidaya dan agribisnis sayuran dataran tinggi pada umumnya dikenal beresiko tinggi dan penuh dengan spekulasi. Selanjutnya, komposisi dan pelaku pasar akan menentukan struktur pasar dan pada gilirannya menentukan proses pembentukan harga pasar (Erwidodo, 1994).

$$
\text { Penelitian ini penting dilakukan }
$$
karena ketersediaan informasi pasar dikalangan petani antara lain tentang informasi harga, jenis-jenis komoditas baru, teknologi usahatani, kualitas produk dan faktor-faktor lainnya diharapkan akan mempermudah proses pengambilan keputusan dalam kegiatan usahatani dan strategi pemasaran sayuran dataran tinggi yang akan dilakukan. Petani dituntut untuk menguasai informasi dan strategi pemasaran sehingga petani dapat mencapai suatu usahatani yang lebih efektif, efisien, produktif dan memiliki posisi tawar (bargaining position) dalam memasarkan produknya atau produk yang dihasilkan lebihkompetitif. mengumpulkan data, menyusun dan menganalisisnya. Penelitian deskriptif bertujuan untuk membuat gambaran hubungan antar fenomena, membuat prediksi serta implikasi suatu masalah yang ingin dipecahkan (Gulo, 2010); (Nasir, 1988). 


\section{Penentuan Lokasi dan Waktu Penelitian}

Lokasi penelitian ditentukan secara purposive di Wilayah Kecamatan Batur (Desa Batur, Sumberejo, Dieng Kulon) Kabupaten Banjarnegara. Alasan pemilihan ketiga desa ini karena lokasi tersebut memiliki pertanaman sayuran dataran tinggi yang luas di banding desa-desa lainnya di wilayah Kecamatan Batur (Pujiharto dkk, 2012), ketiga desa tersebut merupakan sentra produksi sayuran dataran tinggi dan sayuran tersebut dapat ditanam sepanjang musim (Pujiharto, 2013a); (Pujiharto,2013). Jenis komoditi sayuran yang diamati didasarkan pada tiga jenis sayuran yang dominan diusahakan meliputi : kentang, kubis, dan wortel, . Ketiga desa tersebut dianggap mempunyai relevansi dengan kajian yang diteliti (Pujiharto, 2014); (Pujiharto dkk, 2014). Kegiatan pengumpulan data di lapang secara efektif dilakukan selama 3 bulan (April-Juni 2018)

\section{Penentuan Sampel}

Sampel terdiri dari produsen (petani) dan pedagang (pelaku pemasaran). Sampel penelitian produsen adalah petani yang menanam sayuran dataran tinggi dalam satu musim tanam. Masing-masing jenis tanaman sayuran dataran tinggi utama yang diusahakan kentang, kubis, dan wortel diambil sampel sebanyak 10 petani (responden) secara puposive, sehingga jumlah seluruh sampel adalah 90 orang petani $(10$ petani $\times 3$ komoditi utama x 3 desa). Sedangkan sampel pedagang diambil secara sensus dari jumlah pedagang di 3 desa tersebut (12 pedagang pengumpul, 3 pedagang besar).

Pengambilan data dilakukan dengan cara:

1. Observasi yaitu mengadakan pengamatan langsung pada obyek yang diteliti.

2. Wawancara yaitu pengumpulan data dengan jalan mengadakan wawancara langsung, dengan menggunakan daftar pertanyaan (kuisioner) yang sudah disiapkan.

3. Pencatatan yaitu mencatat seluruh data yang dibutuhkan untuk penelitian.

\section{Metode Analisis Data}

1. Strategi pemasaran oleh petani (produsen) sayuran dataran tinggi dianalisis dengan pendekatan strategi harga, distribusi dan promosi (Sudiyono, 2000); (Tjiptono, 2000); (Kohout,1997) sebagai berikut:

a). Strategi harga merupakan cerminan dari dapat diterimanya suatu produk oleh para konsumen, sedangkan disisi lain dalam hal ini produsen merasa diuntungkan. Uraian indikator dan nilai skala variabel harga pada tabel 1 . 
Tabel 1. Deskripsi Strategi Harga dalam Pemasaran.

\begin{tabular}{|c|l|c|l|l|}
\hline No & \multicolumn{1}{|c|}{ Deskripsi strategi harga } & \multicolumn{3}{|c|}{ Pilihan jabawan responden } \\
\cline { 3 - 5 } & & Tinggi & \multicolumn{1}{|c|}{ Sedang } & \multicolumn{1}{|c|}{ Rendah } \\
\hline 1 & $\begin{array}{l}\text { Menganalisis harga pasar } \\
\text { pesaing sayuran }\end{array}$ & Sering & $\begin{array}{l}\text { Kadang- } \\
\text { kadang }\end{array}$ & $\begin{array}{l}\text { Kadang- } \\
\text { kadir tidak } \\
\text { kadang }\end{array}$ \\
\hline 2 & $\begin{array}{l}\text { Merumuskan kebijakan penetap } \\
\text { an harga sayuran }\end{array}$ & $\begin{array}{l}\text { Hampir tidak } \\
\text { pernah }\end{array}$ \\
\hline 3 & Menetapkan harga produk & Sering & $\begin{array}{l}\text { Kadang- } \\
\text { kadang }\end{array}$ & $\begin{array}{l}\text { Hampir tidak } \\
\text { pernah }\end{array}$ \\
\hline 4 & $\begin{array}{l}\text { Memutuskan pemotongan harga } \\
\text { untuk berbagai jenis pembeli; }\end{array}$ & Sering & $\begin{array}{l}\text { Kadang- } \\
\text { kadang }\end{array}$ & $\begin{array}{l}\text { Hampir tidak } \\
\text { pernah }\end{array}$ \\
\hline 5 & $\begin{array}{l}\text { Menetapkan persyaratan } \\
\text { penjualan hasil menyangkut } \\
\text { pembayaran }\end{array}$ & Sering & $\begin{array}{l}\text { Kadang- } \\
\text { kadang }\end{array}$ & $\begin{array}{l}\text { Hampir tidak } \\
\text { pernah }\end{array}$ \\
\hline
\end{tabular}

b). Strategi distribusi merupakan kegiatan pemasaran yang berusaha memperlancar dan mempermudah penyampaian produk sayuran dataran tinggi dari produsen ke konsumen.

Tabel 2. Deskripsi Strategi Distribusi dalam Pemasaran.

\begin{tabular}{|c|l|c|l|l|}
\hline \multirow{2}{*}{ No } & \multicolumn{1}{|c|}{ Deskripsi strategi distribusi } & \multicolumn{3}{|c|}{ Pilihan jabawan responden } \\
\cline { 3 - 5 } & & Tinggi & \multicolumn{1}{|c|}{ Sedang } & \multicolumn{1}{|c|}{ Rendah } \\
\hline 1 & $\begin{array}{l}\text { Menganalisis berbagai jalur } \\
\text { distribusi }\end{array}$ & Sering & $\begin{array}{l}\text { Kadang- } \\
\text { kadang }\end{array}$ & $\begin{array}{l}\text { Hampir tidak } \\
\text { pernah }\end{array}$ \\
\hline 2 & $\begin{array}{l}\text { Merancang jalur distribusi baru } \\
\text { yang sesuai untuk pengembang- } \\
\text { an pasaran yang sudah ada }\end{array}$ & Sering & $\begin{array}{l}\text { Kadang- } \\
\text { kadang } \\
\text { pernah }\end{array}$ \\
\hline 3 & $\begin{array}{l}\text { Merancang program yang efektif } \\
\text { untuk berhubungan dengan para } \\
\text { pelaku penyalur }\end{array}$ & Sering & $\begin{array}{l}\text { Kadang- } \\
\text { kadang }\end{array}$ & $\begin{array}{l}\text { Hampir tidak } \\
\text { pernah }\end{array}$ \\
\hline 4 & $\begin{array}{l}\text { Menetapkan pusat-pusat } \\
\text { distribusi }\end{array}$ & Sering & $\begin{array}{l}\text { Kadang- } \\
\text { kadang }\end{array}$ & $\begin{array}{l}\text { Hampir tidak } \\
\text { pernah }\end{array}$ \\
\hline 5 & $\begin{array}{l}\text { Merumuskan dan melaksanakan } \\
\text { prosedur untuk penanganan } \\
\text { produk yang efisien }\end{array}$ & Sering & $\begin{array}{l}\text { Kadang- } \\
\text { kadang }\end{array}$ & $\begin{array}{l}\text { Hampir tidak } \\
\text { pernah }\end{array}$ \\
\hline 6 & $\begin{array}{l}\text { Menetapkan pengendalian } \\
\text { persediaan dipasaran }\end{array}$ & Sering & $\begin{array}{l}\text { Kadang- } \\
\text { kadang }\end{array}$ & $\begin{array}{l}\text { Hampir tidak } \\
\text { pernah }\end{array}$ \\
\hline 7 & $\begin{array}{l}\text { Menganalisis metode tranportasi } \\
\text { yang efektif dan efisien }\end{array}$ & Sering & $\begin{array}{l}\text { Kadang- } \\
\text { kadang }\end{array}$ & $\begin{array}{l}\text { Hampir tidak } \\
\text { pernah }\end{array}$ \\
\hline 8 & $\begin{array}{l}\text { Meminimumkan biaya } \\
\text { transportasi }\end{array}$ & Sering & $\begin{array}{l}\text { Kadang- } \\
\text { kadang }\end{array}$ & $\begin{array}{l}\text { Hampir tidak } \\
\text { pernah }\end{array}$ \\
\hline 9 & $\begin{array}{l}\text { Meminimumkan biaya distribusi } \\
\text { secara keseluruhan }\end{array}$ & Sering & $\begin{array}{l}\text { Kadang- } \\
\text { kadang }\end{array}$ & $\begin{array}{l}\text { Hampir tidak } \\
\text { pernah }\end{array}$ \\
\hline 10 & $\begin{array}{l}\text { Menganalisis kemungkinan } \\
\text { saluran distribusi pemasaran } \\
\text { yang baru. }\end{array}$ & Sering & $\begin{array}{l}\text { Kadang- } \\
\text { kadang }\end{array}$ & $\begin{array}{l}\text { Hampir tidak } \\
\text { pernah }\end{array}$ \\
\hline
\end{tabular}

c). Strategi promosi merupakan suatu bentuk komunikasi pemasaran. Komunikasi pemasaran adalah aktivitas pemasaran yang berusaha menyebarkan informasi, mempengaruhi/membujuk, dan /atau mengingatkan pasar sasaran atas usahatani 
Pujiharto, STRATEGI PEMASARAN PRODUK ...

agar produknya bersedia diterima., membeli

dan loyal pada produk yang ditawarkan.

Tabel 3. Deskripsi Strategi Promosi dalam Pemasaran.

\begin{tabular}{|c|l|l|l|l|}
\hline No & \multicolumn{1}{|c|}{ Strategi promosi } & \multicolumn{3}{|c|}{ Pilihan jabawan responden } \\
\cline { 3 - 5 } & \multicolumn{1}{|c|}{ Tinggi } & \multicolumn{1}{|c|}{ Sedang } & \multicolumn{1}{|c|}{ Rendah } \\
\hline 1 & $\begin{array}{l}\text { Menetapkan tujuan promosi } \\
\text { usahatani sayuran }\end{array}$ & Sering & $\begin{array}{l}\text { Kadang- } \\
\text { kadang }\end{array}$ & $\begin{array}{l}\text { Hampir tidak } \\
\text { pernah }\end{array}$ \\
\hline 2 & $\begin{array}{l}\text { Menetapkan jenis promosi } \\
\text { utama yang akan dipergunakan; }\end{array}$ & Sering & $\begin{array}{l}\text { Kadang- } \\
\text { kadang }\end{array}$ & $\begin{array}{l}\text { Hampir tidak } \\
\text { pernah }\end{array}$ \\
\hline 3 & Menetapkan wilayah penjualan & Sering & $\begin{array}{l}\text { Kadang- } \\
\text { kadang }\end{array}$ & $\begin{array}{l}\text { Hampir tidak } \\
\text { pernah }\end{array}$ \\
\hline 4 & $\begin{array}{l}\text { Mengikuti dan melaksanakan } \\
\text { usaha-usaha promosi penjualan } \\
\text { seperti sample gratis, pameran } \\
\text { dan program pengiklanan } \\
\text { kerjasama pemerintah dan } \\
\text { pengusaha besar }\end{array}$ & Sering & $\begin{array}{l}\text { Kadang- } \\
\text { kadang }\end{array}$ & $\begin{array}{l}\text { Hampir tidak } \\
\text { pernah }\end{array}$ \\
\hline 5 & $\begin{array}{l}\text { Mempersiapkan dan } \\
\text { menyebarkan berita-berita } \\
\text { publisistas. }\end{array}$ & Sering & $\begin{array}{l}\text { Kadang- } \\
\text { kadang }\end{array}$ & $\begin{array}{l}\text { Hampir tidak } \\
\text { pernah }\end{array}$ \\
\hline
\end{tabular}

\section{HASIL DAN PEMBAHASAN}

\section{Strategi Pemasaran Sayuran Dataran Tinggi yang Dilakukan oleh Petani.}

\subsection{Strategi Harga Dalam Pemasaran}

Strategi harga yang diimplementasikan oleh petani sayuran dataran tinggi di Kecamatan Batur dilihat dari beberapa indikator antara lain kemampuan petani dalam: 1). menganalisis harga pasar pesaing sayuran; 2). merumuskan kebijakan penetapan harga sayuran; 3) menetapkan harga; 4) memutuskan pemotongan harga untuk berbagai jenis pembeli; 5) menetapkan persyaratan penjualan.
Hasil uji validitas strategi harga menunjukkan bahwa dari 5 item pertanyaan yang diajukan ternyata semuanya mempunyai nilai koefisien korelasinya lebih besar dari rtabel $(0,205)$, selanjutnya uji reliabilitas menunjukkan nilai Alpha 0,7787 lebih besar dari r-tabel $(0,205)$, berdasar hal tersebut, maka intrumen pengambilan data variabel strategi harga valid (handal) dan reliable (dapat dipercaya). Hasil pengamatan strategi harga yang diimplementasikan sebagai salah satu strategi dalam pemasaran sayuran oleh petani disajikan pada tabel 4 . 
Tabel 4. Implementasi Strategi Pemasaran dalam Indikator Harga oleh Petani Sayuran Dataran Tinggi.

\begin{tabular}{lcccccc}
\hline \multirow{2}{*}{ Kategori } & \multicolumn{6}{c}{ Implementasi Strategi Pemasaran dalam Indikator Harga } \\
\cline { 2 - 7 } & Kentang & Persen & Kubis & Persen & Wortel & Persen \\
\hline Tinggi & 8 & 26,7 & 2 & 6,7 & 6 & 20,0 \\
Sedang & 10 & 33,3 & 4 & 13,3 & 7 & 26,3 \\
Rendah & 12 & 30.0 & 24 & 80,0 & 17 & 56,7 \\
\hline Jumlah & 30 & 100 & 30 & 100 & 30 & 100 \\
\hline Keterangan: & & & & & & \\
Tinggi & $: 11,8-15,0$ & & & & \\
Sedang & $: 8,4-11,7$ & & & & \\
Rendah & $: 5,0-8,3$ & & & &
\end{tabular}

Tabel 4, terlihat bahwa tingkat implementasi strategi harga yang dilakukan oleh petani berada pada kategori rendah. Hal ini disebabkan terbatasnya kemapuan petani dalam menganalisis informasi harga pesaing dan tidak adanya pilihan bagi petani untuk membentuk harga yang lebih tinggi karena sebagian besar petani membutuhkan dana yang menjadikan satu-satunya penghasilan yang diharapkan.

\subsection{Strategi Produk Dalam Pemasaran}

Keputusan mengenai produk merupakan keputusan yang paling nyata dalam pengambilan keputusan. Seandainya produk yang dihasilkan tidak berorientasi kepada keinginan pasar, petani akan merugi lebih besar. Produk yang dipadukan dalam bauran produk harus saling melengkapi, baik dalam saluran pemasaran, maupun dalam pemenuhan kebutuhan pelanggan, sehingga petani dapat menikmati manfaat penuh dari efisiensi pemasaran. Untuk melihat kriteria pengukuran variabel produk dilihat antara lain
: 1) mengembangkan pasar produk; 2). menguji pasar produk baru; 3). memodifikasi produk yang ada; 4). menyingkirkan produk yang tidak memenuhi keinginan konsumen; 5) merumuskan nama merek dan kebijakankebijakan tentang merek; 6). menetapkan garansi produk dan prosedur untuk pemenuhan garansi; 7). merencanakan kemasan, termasuk bahan ukuran, bentuk, dan rancangan.

Hasil uji validitas strategi produk menunjukkan bahwa dari 7 item pertanyaan yang diajukan ternyata semuanya mempunyai nilai koefisien korelasinya lebih besar dari rtabel (0,205), selanjutnya uji reliabilitas menunjukkan nilai Alpha 0,7438 lebih besar dari r-tabel $(0,205)$, berdasar hal tersebut, maka intrumen pengambilan data variabel strategi harga valid (handal) dan reliable (dapat dipercaya). Hasil pengamatan strategi produk yang diimplementasikan sebagai salah satu strategi dalam pemasaran sayuran oleh petani disajikan pada tabel 5 . 
Tabel 5. Implementasi Strategi Pemasaran dalam Indikator Produk oleh Petani Sayuran Dataran Tinggi.

\begin{tabular}{lcccccc}
\hline \multirow{2}{*}{ Kategori } & \multicolumn{6}{c}{ Implementasi Strategi Pemasaran dalam Indikator Harga } \\
\cline { 2 - 7 } & Kentang & Persen & Kubis & Persen & Wortel & Persen \\
\hline Tinggi & 3 & 10,0 & - & & - & \\
Sedang & 13 & 43,3 & 12 & 40,0 & 15 & 50,0 \\
Rendah & 14 & 46,7 & 18 & 60,0 & 15 & 50,0 \\
\hline Jumlah & 30 & 100 & 30 & 100 & 30 & 100 \\
\hline Keterangan: & \multicolumn{7}{c}{} & & & & \\
Tinggi & $: 16,5-21,0$ & & & & \\
Sedang & $: 11,7-16,4$ & & & & \\
Rendah & $: 7,0-11,0$ & & & &
\end{tabular}

Tabel 5, terlihat bahwa tingkat implementasi strategi produk yang dilakukan oleh petani berada pada kategori rendah. Hal ini disebabkan terbatasnya kemapuan petani dalam menganalisis informasi produk dari permintaan pasar dan adanya anggapan dari

\subsection{Strategi Distribusi dalam Pemasaran}

Tujuan dari strategi distribusi adalah melayani pasar dengan biaya yang minimal namun bisa menciptakan citra produk yang diinginkan. Guna mengukur distribusi seefektif mungkin maka disusun sesuai dengan keadaan petani sayuran dataran tinggi di Kecamatan Batur Kabupaten Banjarnegara antara lain: 1). menganalisis berbagai jalur distribusi; 2). merancang jalur distribusi baru yang sesuai untuk pengembangan pasaran yang sudah ada; 3 ). merancang program yang efektif untuk berhubungan dengan para pelaku penyalur; 4). menetapkan pusat-pusat distribusi; 5). merumuskan dan melaksanakan prosedur untuk penanganan produk yang efisien; 6). menetapkan pengendalian persediaan dipasaran; 7). menganalisis petani bahwa nanti pedagang akan menghargai produk mereka akan sama dengan produk apa yang telah ia perbuat sebelumnya

metode tranportasi yang efektif dan efisien; 8). meminimumkan biaya transportasi; 9). meminimumkan biaya distribusi secara keseluruhan; 10) menganalisis kemungkinan saluran distribusi pemasaran yang baru.

Hasil uji validitas strategi distribusi menunjukkan bahwa dari 10 item pertanyaan yang diajukan ternyata semuanya mempunyai nilai koefisien korelasinya lebih besar dari rtabel (0,205), selanjutnya uji reliabilitas menunjukkan nilai Alpha 0,8444 lebih besar dari r-tabel $(0,205)$, berdasar hal tersebut, maka intrumen pengambilan data variabel strategi harga valid (handal) dan reliable (dapat dipercaya). Hasil pengamatan strategi distribusi yang diimplementasikan sebagai 
Pujiharto, STRATEGI PEMASARAN PRODUK ...

salah satu strategi dalam pemasaran sayuran

oleh petani disajikan pade tabel 6 .

Tabel 6 Implementasi Strategi Pemasaran dalam Indikator Distribusi oleh Petani Sayuran Dataran Tinggi..

\begin{tabular}{lcccccc}
\hline \multirow{2}{*}{ Kategori } & \multicolumn{6}{c}{ Implementasi Strategi Pemasaran dalam Indikator Distribusi } \\
\cline { 2 - 7 } & Kentang & Persen & Kubis & Persen & Wortel & Persen \\
\hline Tinggi & 5 & 16,7 & - & & 3 & 10,0 \\
Sedang & 6 & 20,0 & 2 & 6,7 & 6 & 20,0 \\
Rendah & 19 & 63,3 & 28 & 93,3 & 21 & 70,0 \\
\hline Jumlah & 30 & 100 & 30 & 100 & 30 & 100 \\
\hline Keterangan: & \multicolumn{7}{c}{} & & & & \\
Tinggi & $: 23,1-30,0$ & & & & \\
Sedang & $: 16,1-23,0$ & & & & \\
Rendah & $: 10,0-16,0$ & & & & &
\end{tabular}

Tabel 6 terlihat bahwa tingkat implementasi strategi distribusi yang dilakukan oleh petani sayuran dataran tinggi berada pada kategori rendah.. Hal ini disebabkan terbatasnya kemapuan petani dalam menganalisis informasi distribusi dari permintaan pasar dan adanya anggapan dari petani bahwa distribusi yang berubah akan menambah biaya yang harus mereka keluarkan.

\subsection{Strategi Promosi dalam Pemasaran}

Strategi promosi pada dasarnya merupakan proses komunikasi yang ditujukan untuk memodifikasi perilaku konsumen kearah pengambilan keputusan yang positif dalam pembelian (Keegan, 1997). Adapun tujuan dari promosi adalah menginformasikan, mempengaruhi dan membujuk, serta mengingatkan pelanggan sasaran tentang produk yang ditawarkan oleh produsen (Kotler, 1980). Untuk melihat dan mengukur adanya promosi yang dilakukan oleh petani tersebut maka, digunakan beberapa indikator sebagai beriku: 1). menetapkan tujuan promosi usahatani sayuran dataran tinggi; 2). menetapkan jenis promosi utama yang akan dipergunakan; 3). menetapkan wilayah penjualan; 4). merencanakan dan melaksanakan usaha-usaha promosi penjualan seperti sample gratis, pameran, dan program pengiklanan kerjasama; 5). mempersiapkan dan menyebarkan berita-berita publisistas.

Hasil uji validitas strategi promosi menunjukkan bahwa dari 5 item pertanyaan yang diajukan ternyata semuanya mempunyai nilai koefisien korelasinya lebih besar dari rtabel $(0,205)$, selanjutnya uji reliabilitas menunjukkan nilai Alpha 0,7850 lebih besar dari r-tabel $(0,205)$, berdasar hal tersebut, maka intrumen pengambilan data variabel strategi harga valid (handal) dan reliable (dapat dipercaya). Hasil pengamatan strategi promosi yang diimplementasikan sebagai salah satu strategi dalam pemasaran sayuran oleh petani disajikan pada tabel 7 . 
Pujiharto, STRATEGI PEMASARAN PRODUK ...

Tabel 7 Implementasi Strategi Pemasaran dalam Indikator Promosi oleh Petani Sayuran Dataran Tinggi.

\begin{tabular}{lcccccc}
\hline \multirow{2}{*}{ Kategori } & \multicolumn{6}{c}{ Implementasi Strategi Pemasaran dalam Indikator Distribusi } \\
\cline { 2 - 7 } & Kentang & Persen & Kubis & Persen & Wortel & Persen \\
\hline Tinggi & 4 & 13,3 & 1 & 3,3 & - & - \\
Sedang & 7 & 23,4 & 1 & 3,3 & 2 & 6,7 \\
Rendah & 19 & 63,3 & 28 & 93,3 & 28 & 93,3 \\
\hline Jumlah & 30 & 100 & 30 & 100 & 30 & 100 \\
\hline Keterangan: & & & & & & \\
Tinggi & $: 11,1-15,0$ & & & & \\
Sedang & $:$ & $8,1-11,0$ & & & & \\
Rendah & $: 5,0-8,0$ & & & &
\end{tabular}

Tabel 7 terlihat bahwa tingkat implementasi strategi promosi yang dilakukan oleh petani berada pada kategori rendah. Hal ini dikarenakan untuk menggalang kegiatan promosi bagi petani sayuran dataran tinggi yang pada umumnya mengusahakan dalam skala kecil sangat tidak mudah, hal ini karena sifat produk yang bersifat habis sekali pakai, dan disamping itu juga produk homogen yang

\section{KESIMPULAN DAN SARAN}

\section{Kesimpulan}

1. Strategi yang dilakukan oleh petani sayuran dataran tinggi dalam pemasaran produk pada indikator harga, produk, distribusi dan promosi tergolong rendah.

2. Sikap petani terhadap strategi pemasaran mempangaruhi bauran pemasaran pada semua indikator (harga, produk, distribusi dan promosi) sehingga harus ada sikap positif terhadap strategi pemasraran. dapat dihasilkan oleh petani siapa saja. Seorang petani akan tidak mampu mempengaruhi pasar permintaan dan mengendalikannya sendiri karena keterbatasan produksinya. Selain itu adanya anggapan dari petani bahwa kegiatan promosi akan menambah biaya yang harus mereka keluarkan.

\section{Saran}

Hendaknya pemerintah memberikan fasilitas untuk mengakses informasi berkaitan dengan pemasaran produk sayuran dataran tinggi maka petani lebih mudah dalam mengetahui harga, produk yang diminta, sistem ditribisi dan promosi. Sehingga petani dapat menentukan strategi pemasaran sayuran dataran tinggi dengan tepat. 


\section{DAFTAR PUSTAKA}

Ameriana, M dan Soetiarso, T.A. 1997. Keterkaitan Petani Cabai dalam Mengisi Peluang Pasar Industri Pengolahan Makanan, Jurnal Hortikultura 6 (5) hal. 516-523.

Erwidodo. 1994. Agribisnis Hortikultura dan Peluang Ekspor di Segitiga Pertumbuhan Indonesia-MalaysiaThailand, disampaikan temu tugas dalam Aplikasi Teknologi di Aceh 5-7 Januari 1994.

Gulo, W. H. 2010. Metodologi Penelitian. Penerbit PT. Gramedia, Jakarta

Keegan, W.J. 1997. Manajemen Pemasaran Global. Penerbit Perhalindo, Jakarta.

Kohout, F. 1997. Statistic for Social Scientist. A Coordinataed Learning System A Wiley. Trans-Edition \&Sons Inc. Nem York, London, Sydney, Toronto.

Kotler P. 1980. Marketing Management: Analisis, Planning and Control, Fouth Edition Prentice Hall, USA.

Nasir, M. 1988. Metode Ilmiah. Penerbit Ghalia. Jakarta.

Pujiharto; Dwidjono H.D.; Slamet H; Masyhuri. 2012. Perilaku Petani terhadap Risiko Usahatani Kentang di Sentra Produksi Kabupaten Banjarnegara. Jurnal AGROS Fakultas Pertanian Universitas Janabadra, ISSN
: 1411-0172. Vol. 14 No. 2 Juli 2012

Halaman : 264-280

Pujiharto. 2013a. Farmers Behavior Toward Risks of Potato Farming for Granola and Atlantic Varieties in Banjarnegara Regency. Laporan Penelitian Hibah Bersaing Universitas Muhammadiyah Purwokerto.

Pujiharto. 2013. Produktivitas, Pendapatan dan Perilaku Petani terhadap Risiko Usahatani Kentang Varietas Granola dan Atlantic di Sentra Produksi Kabupaten Banjarnegara. Disertasi Program Doktor Ekonomi Pertanian UGM tidak dipublikasikan

Pujiharto. 2014. Model Pengukuran Perilaku Petani terhadap Risiko Usahatani Kentang: Sebuah Pendekatan Ekonometrik. Laporan Penelitian Hibah Disertasi Doktor Kemenristek Dikti.

Pujiharto, Sri Wahyuni. 2014. Model Pengembangan Tataniaga Sayuran Dataran Tinggi Berbasis Kelembagaan Sub Terminal Agribisnis. Laporan Penelitian Hibah Bersaing Kemenristek Dikti.

Sudiyono, S. 2000. Pemasaran Pertanian. UMM Press, Universitas Muhammadiyah Malang.

Tjiptono, F. 2000. Strategi Pemasaran. Penerbit Andi Offset, Yogyakarta. 